\title{
Epilepsy, Physical Activity and Sports: A Narrative Review
}

\author{
Jaime Carrizosa-Moog, Lady Diana Ladino, Vanessa Benjumea-Cuartas, \\ Juan Pablo Orozco-Hernández, Diana Marcela Castrillón-Velilla, Syed Rizvi, \\ José Francisco Téllez-Zenteno
}

\begin{abstract}
People with epilepsy (PWE) are less physically active compared with the general population. Explanations include prejudice, overprotection, unawareness, stigma, fear of seizure induction and lack of knowledge of health professionals. At present, there is no consensus on the role of exercise in epilepsy. This paper reviews the current evidence surrounding the risks and benefits associated with physical activity (PA) in this group of patients. In the last decade, several publications indicate significant benefits in physiological and psychological health parameters, including mood and cognition, physical conditioning, social interaction, quality of life, as well as potential prevention of seizure presentation. Moreover, experimental studies suggest that PA provides mechanisms of neuronal protection, related to biochemical and structural changes including release of $\beta$-endorphins and steroids, which may exert an inhibitory effect on the occurrence of abnormal electrical activity. Epileptic discharges can decrease or disappear during exercise, which may translate into reduced seizure recurrence. In some patients, exercise may precipitate seizures. Available evidence suggests that PA should be encouraged in PWE in order to promote wellbeing and quality of life. There is a need for prospective randomized controlled studies that provide stronger clinical evidence before definitive recommendations can be made.
\end{abstract}

RÉSUMÉ: Épilepsie, activité physique et pratique de sports : une revue non systématique. Les individus atteints d'épilepsie font en moyenne moins d'activité physique que la population en général. Parmi les explications avancées, on peut évoquer le fait de nourrir des préjugés à l'égard de l'exercice, une volonté de surprotection, la méconnaissance, la honte, la peur de provoquer des convulsions et un manque de connaissances de la part des professionnels de la santé les traitant. Pour l'instant, il n'existe aucun consensus quant au rôle que peut jouer l'activité physique chez des patients atteints d'épilepsie. Cet article entend passer en revue les preuves actuelles portant sur les risques et les bénéfices associés à l'activité physique dans le cas de patients atteints d'épilepsie. Au cours des dernières décennies, plusieurs publications ont montré l'existence de bienfaits importants tant en ce qui regarde des paramètres de santé physiologique que des paramètres de santé mentale, ce qui inclut l'humeur et les fonctions cognitives, la condition physique, le maintien d'interactions sociales, la qualité de vie de même que la capacité potentielle à prévenir de nouvelles crises convulsives. Qui plus est, des études expérimentales ont suggéré que l'activité physique fournissait des mécanismes de protection neuronale liés à des modifications structurales et biochimiques, par exemple la production de béta-endorphines et de stéroïdes, qui pourraient exercer un effet inhibiteur sur le déclenchement d'une activité cérébrale électrique anormale. Les décharges épileptiques peuvent en effet diminuer ou disparaitre pendant l'activité physique, ce qui pourrait se traduire par une réduction de la récurrence des crises convulsives. Chez un nombre réduit de patients, le fait d'être physiquement actif peut toutefois entraîner de telles crises. Cela dit, les données disponibles donnent à penser que l'activité physique devrait quand même être encouragée chez les individus atteints d'épilepsie, et ce, afin de promouvoir leur bien-être et leur qualité de vie. Avant d'émettre des recommandations définitives, nous avons toutefois encore besoin d'études prospectives contrôlées à répartition aléatoire qui reposeraient sur des données cliniques plus solides.

Key words: Barriers, Benefits, Complementary Medicine, Exercise, Physical training, Wellbeing

doi: $10.1017 / \operatorname{cjn} .2018 .340$

Can J Neurol Sci. 2018; 45: 624-632

\section{BACKGROUND}

Epilepsy is a highly prevalent chronic neurological disease. Approximately 50 million people have epilepsy worldwide, with $80 \%$ residing in developing countries. ${ }^{1}$ Epilepsy is commonly associated with somatic, cognitive and psychiatric comorbidities such as anxiety and depression, which negatively impact quality of life. ${ }^{2}$

Epileptic seizures are unpredictable and sometimes occur without aura, leading to a sense of loss of control with negative effects on self-esteem and often force patients to make significant lifestyle changes. Despite evidence to the contrary, patients and clinicians may suffer the false pretense that physical activity (PA) is injurious to wellbeing. ${ }^{3}$ Several studies have demonstrated the benefits of PA with respect to improved quality of life, seizure control, mental health ${ }^{4-6}$ and a reduction in the interictal epileptiform discharges (IEDs) as seen on the electroencephalogram (EEG). ${ }^{4}$ These findings are encouraging and may support a role for PA as a complementary therapeutic strategy in the treatment of epilepsy. ${ }^{7,8}$

From the Pediatrics Department, Faculty of Medicine, University of Antioquia, Medellin, Colombia (JCM); Epilepsy Program, Hospital Pablo Tobón Uribe, University of Antioquia, Neuroclínica, Medellin, Colombia (LDL, DMCV); Epilepsy Program, Neuromédica, Medellín, Colombia (VBC); Facultad de Ciencias de la Salud, Universidad Tecnológica de Pereira, Pereira, Colombia (JPOH); Department of Medicine, Division of Neurology, Saskatchewan Epilepsy Program, Royal University Hospital, University of Saskatchewan, Saskatoon, Saskatchewan, Canada (SR, JFTZ).

Received March 14, 2018. Final Revisions Submitted August 12, 2018. Date of ACCEPTANCE August 14, 2018.

Correspondence to: J. Carrizosa-Moog, Department of Pediatrics, Faculty of Medicine, University of Antioquia, Calle 18 B Sur No. 38-51, Medellín, Colombia.

Email: jcarrizosa25@gmail.com 


\section{Material AND Methods}

We performed a narrative review with the aim of providing a summary of the evidence surrounding risks and benefits of PA in people with epilepsy (PWE). The literature search was performed using Medline ${ }^{\circ}$, Embase ${ }^{\circledR}$, Index Medicus $\AA$, Google Scholars, Current Contents and Cochrane databases for articles published from 1960 to July 2017. The search included both medical subject headings and text words for literature on PA and epilepsy. The following keywords were used: activity, activities, athletic, epilepsy, electroencephalogram, EEG, epileptiform discharge, exercise, fitness, game, health behaviors, leisure, leisure time, outdoor, recreational, physical activity, physical effort, physical training, quality of life, recreation, seizure, sports, wellness and wellbeing. We included reviews, original articles and book chapters. Experts were consulted about unpublished studies. Article bibliographies were screened to identify additional sources.

Titles and abstracts were reviewed for original articles regarding effects of PA and sports on epilepsy in animals, children and adults. We included case reports, case series, cohorts, clinical trials and meta-analysis, regardless of language or country of origin. Two authors (JCM, LDL) independently screened and reviewed all the documents.

Five questions were posed:

1) What is the current state of PA in PWE?

2) What are the clinical effects of PA in this population?

3) Does PA reduce the number of IEDs seen on EEG and impact seizure frequency?

4) Which mechanisms related to PA could explain improved seizure control?

5) Can PA adversely affect seizure control?

\section{Results}

A total of 167 articles were identified, and after titles and abstracts were reviewed, we excluded 101 documents. Among them, 66 full-text articles were reviewed, including original articles, clinical trials and meta-analysis (see Figure 1).

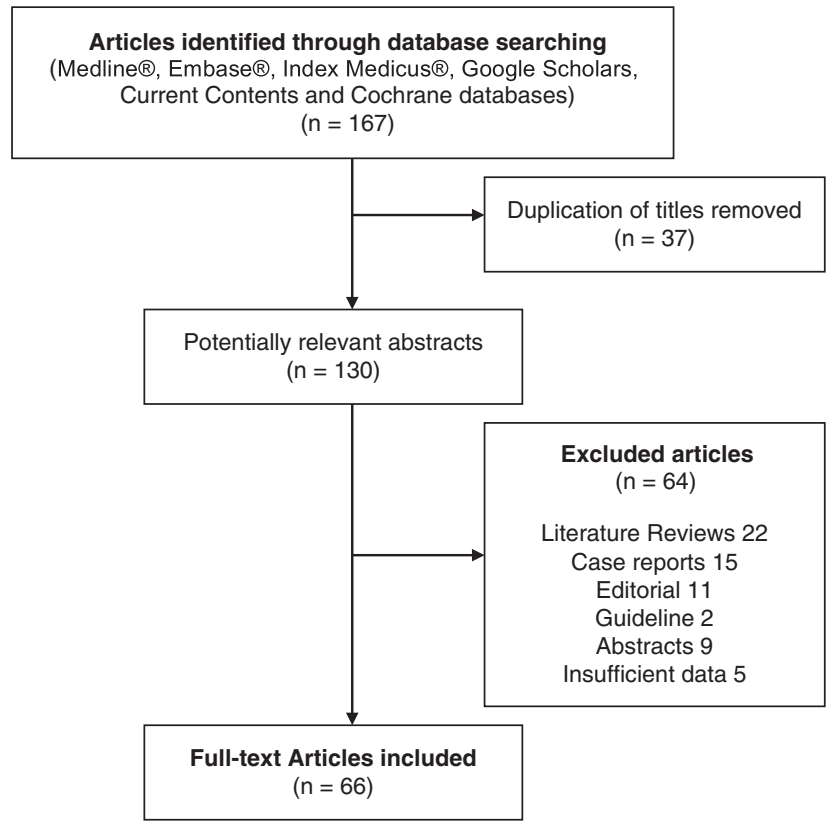

Figure 1: Flowchart of the literature search.

\section{What is the Present State of PA in PWE?}

The data on PA and sports in PWE are limited but tend to indicate lower levels of engagement compared with the general population. A survey conducted in Ohio, United States (US) revealed that while $47 \%$ of PWE were instructed to be more physically active versus $35 \%$ of controls, only $58 \%$ of PWE performed PA compared with $76 \%$ of controls. ${ }^{9}$

Similarly, a Norwegian study reported that sedentary lifestyle was more prevalent in PWE compared with controls (25\% vs. $13 \%, p<0.05){ }^{10}$ Another study from the US Midwest documented that PWE performed low-intensity PA $\leq 3$ times per week. ${ }^{11}$ A German study demonstrated that controls were more likely to engage in sports on a regular basis (42\% of controls vs. $25 \%$ of PWE) and less likely to state that they never played sports (15\% of controls vs. $31 \%$ of PWE). The authors indicated that PWE were instructed to refrain from sports by teachers, instructors and even doctors. ${ }^{12}$

In their Brazilian study, Arida et al reported that $49 \%$ of the PWE did not perform PA on a regular basis. The reasons for this phenomenon included recommendations by relatives, friends and physicians, fear and embarrassment of having a seizure in public, lack of time or motivation, fatigue and absence of company, among others. ${ }^{13}$ Identical results were seen in a Korean investigation which documented low PA participation owing to factors such as anxiety, polypharmacy and having experienced a seizure during exercise. ${ }^{14}$

A Canadian population-based study revealed that $60 \%$ of PWE reported being sedentary. Individuals with epilepsy had a higher likelihood of being physically inactive compared with the general population (odds ratio [OR]: 1.4, confidence interval [CI] 95\% 1.1-1.7). ${ }^{15}$ The 2010 US National Health Survey revealed that PWE were less likely to follow health guidelines concerning PA. For instance, when asked whether participants had walked at least 10 minutes in the past week, only $39 \%$ of PWE indicated they had versus $50 \%$ in the general population. ${ }^{16}$

Wong and Wirrell determined that adolescents with epilepsy were less likely to be involved in sports groups or engaged in PA and were more likely to be overweight and obese than siblings without the disease. ${ }^{17}$ In Thailand, $38 \%$ of PWE surveyed did not perform PA on a regular basis. ${ }^{18}$

This trend may be reversible as evidenced by an epilepsy program which enrolled PWE in physical activities in Arizona and was able to achieve a reduction in activity-limited days. ${ }^{19}$

Some studies have failed to document differences in activity levels. In Finland, Jalava et al did not detect any significant difference between PWE and controls in terms of PA frequency. Nonetheless, 9\% of PWE reported being physically inactive compared with $2 \%$ of controls. The same study found performance below expected levels in tests of muscle strength in people with a history of seizures. ${ }^{20}$ Similar results were reported in another California-based study. However, in this study, PA was not addressed during routine medical consultation in the preceding year in $56 \%$ of appointments. ${ }^{21}$ A Nova Scotia-based Canadian investigation did not relate any difference in PA levels but again revealed that PWE were less likely to participate in sports such as hockey or weight lifting and less likely to engage in PA at home. $^{22}$

The preponderance of data would suggest that PWE are less active than their peers due to a variety of reasons such as 
Table 1: Studies on physical exercise and epilepsy

\begin{tabular}{|c|c|c|c|c|}
\hline $\begin{array}{l}\text { Country - } \\
\text { Year }\end{array}$ & Study design & $\begin{array}{l}\text { Patients } N / \\
\text { controls } N\end{array}$ & Results of exercise on epilepsy & Observations \\
\hline $\begin{array}{r}\text { Germany } \\
1996^{12}\end{array}$ & $\begin{array}{l}\text { Controlled study based on a questionnaire and } \\
\text { standardized clinical tests of physical fitness }\end{array}$ & $135 / 145$ & $\begin{array}{l}\text { Controls participated in regular sports more frequently }(p=0.005) \text {. Aerobic } \\
\text { endurance }(p<0.001) \text {, muscle strength }(p<0.001) \text {, and physical flexibility } \\
(p<0.001) \text { was better in the controls } \\
\text { The BMI was significantly higher in PWE }(p=0.03)\end{array}$ & $\begin{array}{l}\text { Epilepsy might have a negative impact on PA frequency and } \\
\text { physical fitness }\end{array}$ \\
\hline $\begin{array}{c}\text { Norway } \\
1997^{4}\end{array}$ & $\begin{array}{l}\text { Case series of children with drug-resistant } \\
\text { partial and generalized epilepsy practicing } \\
\text { exercise during video-EEG }\end{array}$ & $26 / 0$ & $\begin{array}{l}\text { During the exercise epileptiform discharges decreased in } 20 \text { of } 26 \text { children, five } \\
\text { patients showed an atypical EEG response to PA with either unchanged or } \\
\text { increased epileptiform activity }\end{array}$ & $\begin{array}{l}\text { PA may reduce epileptiform discharges on EEG. } \\
\text { EEG may be useful for prediction of PA-induced seizures }\end{array}$ \\
\hline $\begin{array}{l}\text { Finland } \\
1997^{20}\end{array}$ & $\begin{array}{l}\text { Population-based cohort of PWE monitored for } \\
\text { a mean of } 35 \text { years }\end{array}$ & $100 / 100$ & $\begin{array}{l}\text { Muscle tests and physical fitness proved to be significantly poorer in PWE than } \\
\text { in matched controls. Patients perceived their health status to be comparable } \\
\text { with that of controls }\end{array}$ & $\begin{array}{l}\text { Epilepsy might have a negative impact on physical fitness not } \\
\text { perceived by the patients }\end{array}$ \\
\hline $\begin{array}{l}\text { Norway } \\
1999^{10}\end{array}$ & Prospective population-controlled study & $204 / 2336$ & $\begin{array}{l}\text { Sedentary lifestyle was more common in the patient group }(p<0.005), 2 \% \text { had } \\
\text { exercise-induced (partial) seizures. } 36 \% \text { of patients claimed that regular PA } \\
\text { contributed to better seizure control }\end{array}$ & $\begin{array}{l}\text { Epilepsy might be linked to sedentary lifestyle. } \\
\text { There is mild awareness of PA controlling seizures. } \\
\text { There is a chance on exercise-induced seizures in partial } \\
\text { epilepsy }\end{array}$ \\
\hline US $2001^{30}$ & $\begin{array}{l}\text { Randomized, prospective, parallel and } \\
\text { controlled study }\end{array}$ & $14 / 9$ & $\begin{array}{l}\text { The overall quality of life improved in the exercise group }(p<0.031) \text {, while the } \\
\text { control group score did not change }(p=0.943)\end{array}$ & $\begin{array}{l}\text { Exercise is linked to improvement in quality of life. However, } \\
\text { this was a study with a small sample size }\end{array}$ \\
\hline $\begin{array}{l}\text { Brazil } \\
2003^{13}\end{array}$ & $\begin{array}{l}\text { Questionnaire on physical and leisure time } \\
\text { activities at an adult outpatient clinic }\end{array}$ & $100 / 0$ & $\begin{array}{l}50 \% \text { of patients engaged in PA, } 29 \% \text { were forbidden or cautioned by their } \\
\text { physicians, friends or relatives against participation in sports, and 36\% } \\
\text { believed that PA has a positive influence on treatment }\end{array}$ & $\begin{array}{l}\text { There is subjective awareness of PA controlling seizures. } \\
\text { There are misconceptions restraining PA participation }\end{array}$ \\
\hline $\begin{array}{l}\text { Canada } \\
2006^{17}\end{array}$ & $\begin{array}{l}\text { Parent's questionnaire regarding sports } \\
\text { activities }\end{array}$ & $79 / 99$ & $\begin{array}{l}\text { PWE participated less in sports activities than did controls. PWE is more likely to } \\
\text { be overweight. Receiving polytherapy showed a significant negative } \\
\text { correlation with sports participation }\end{array}$ & $\begin{array}{l}\text { Epilepsy might be linked to sedentary lifestyle and overweight. } \\
\text { Particular attention should be paid to patients with drug- } \\
\text { resistant epilepsy }\end{array}$ \\
\hline US $2008^{9}$ & $\begin{array}{l}\text { Ohio survey of the Centers for Disease Control } \\
\text { and Prevention's yearly Behavioral Risk } \\
\text { Factor Surveillance System }\end{array}$ & $96 / 5410$ & $\begin{array}{l}\text { PA was reported by only } 58 \% \text { of PWE compared with } 76 \% \text { of the population } \\
\text { without epilepsy }\end{array}$ & Epilepsy might be linked to sedentary lifestyle \\
\hline US $2008^{21}$ & $\begin{array}{l}\text { California Health Interview Survey in } \\
\text { geographically stratified, random-digit- } \\
\text { dialed, non-institutionalized people in } \\
\text { California }\end{array}$ & $604 / 42,410$ & $\begin{array}{l}\text { PWE engaged in similar levels of regular, moderate or vigorous PA when } \\
\text { compared with the non-epilepsy population }\end{array}$ & $\begin{array}{l}\text { Possible Californian public policy and awareness favor } \\
\text { participation of PWE in PA }\end{array}$ \\
\hline US $2009^{11}$ & $\begin{array}{l}\text { Constructed e-mailed survey to } 412 \text { adult } \\
\text { patients in Kansas }\end{array}$ & $193 / 0$ & $\begin{array}{l}\text { Lack of motivation, limited time and poor access to exercise facilities are an } \\
\text { impediment to PA } \\
\text { Fear of having a seizure, unemployment, and low household income are } \\
\text { factors limiting exercise engagement in PWE }\end{array}$ & $\begin{array}{l}\text { PA engagement of PWE needs a multifactorial approach } \\
\text { trespassing the clinical perspective }\end{array}$ \\
\hline US $2010^{19}$ & $\begin{array}{l}\text { Arizona-based, random-digit-dialed, telephone } \\
\text { survey }\end{array}$ & $125 / 9409$ & $\begin{array}{l}\text { Regression models suggested that for individuals with active epilepsy, PA was } \\
\text { associated with fewer activity-limited days }\end{array}$ & PA might have an impact in reducing labor absenteeism in PWE \\
\hline $\begin{array}{l}\text { Canada } \\
2010^{15}\end{array}$ & $\begin{array}{l}\text { 2001-2005 Canadian Community Health } \\
\text { Survey. Epilepsy, migraine and diabetes } \\
\text { patients and general population }\end{array}$ & $2555 / 397,500$ & $\begin{array}{l}\text { In the logistic regression analysis, epilepsy was associated with physical } \\
\text { inactivity in the past } 12 \text { months compared with the general population } \\
\text { (OR } 1.4,95 \% \text { CI 1.1-1.7) }\end{array}$ & Epilepsy might be linked to sedentary lifestyle \\
\hline $\begin{array}{l}\text { Brazil } \\
2010^{34}\end{array}$ & $\begin{array}{l}\text { Case-control study of physiological and EEG } \\
\text { responses during a cardiopulmonary exercise } \\
\text { test in patients with TLE }\end{array}$ & $19 / 19$ & $\begin{array}{l}\text { Lower aerobic fitness in PWE may be associated with their sedentary habits. } \\
\text { A decrease in the number of epileptiform discharges was observed between } \\
\text { the rest state and exercise }\end{array}$ & $\begin{array}{l}\text { Epilepsy might be linked to sedentary lifestyle. } \\
\text { PA may reduce epileptiform discharges }\end{array}$ \\
\hline $\begin{array}{l}\text { Canada } \\
2010^{22}\end{array}$ & $\begin{array}{l}\text { Health Survey with a cross-sectional, stratified } \\
\text { cluster sample design }\end{array}$ & $341 / 53,211$ & $\begin{array}{l}\text { There was no difference in the monthly frequency of leisure PA of }>15 \text { min } \\
\text { duration between those who did and did not have epilepsy }\end{array}$ & $\begin{array}{l}\text { Possible Canadian public policy and awareness favor sports } \\
\text { participation of PWE }\end{array}$ \\
\hline $\begin{array}{l}\text { South } \\
\text { Korea } \\
2011^{14}\end{array}$ & $\begin{array}{l}\text { Questionnaire assessing PA and leisure time } \\
\text { activities at an adult outpatient clinic }\end{array}$ & $178 / 0$ & $\begin{array}{l}\text { PWE who were on AED polytherapy }(\mathrm{OR}=2.49, p=0.01) \text {, had anxiety } \\
(\mathrm{OR}=3.25, p=0.02) \text { and previous seizure experiences during PA } \\
(\mathrm{OR}=2.84, p=0.01) \text { were more likely to be inactive }\end{array}$ & $\begin{array}{l}\text { Treatment of anxiety, educational programs and being more } \\
\text { effective in the approach of drug-resistant epilepsy could } \\
\text { overcome barriers limiting participation in PA }\end{array}$ \\
\hline
\end{tabular}




\begin{tabular}{|c|c|c|c|c|}
\hline $\begin{array}{l}\text { Brazil } \\
2011^{35}\end{array}$ & $\begin{array}{l}\text { Case-control study: EEG analysis in patients } \\
\text { with JME and healthy subjects at PA }\end{array}$ & $12 / 12$ & $\begin{array}{l}\text { JME group had a significantly lower VO2 at rest and resting metabolic rate. The } \\
\text { number of epileptiform discharges in the JME group was significantly reduced } \\
\text { during the recovery period compared with the resting state }\end{array}$ & $\begin{array}{l}\text { PA may reduce EEG epileptiform discharges. Epilepsy might } \\
\text { have a negative impact on physical fitness. Small sample size }\end{array}$ \\
\hline $\begin{array}{l}\text { Brazil } \\
2013^{29}\end{array}$ & $\begin{array}{l}\text { Prospective controlled study with } \\
\text { questionnaires assessing PA, leisure time } \\
\text { activities and mood disorders in adults }\end{array}$ & $31 / 31$ & $\begin{array}{l}\text { Linear regression analyses showed that low PA leisure level predicted } 31 \% \text { of } \\
\text { depression levels and } 26 \% \text { of anxiety levels }\end{array}$ & Exercise may have a positive impact on depression and anxiety \\
\hline $\begin{array}{l}\text { Israel } \\
2014^{36}\end{array}$ & Prospective controlled study & $26 / 30$ & $\begin{array}{l}\text { Children with generalized epilepsy showed a similar preference for participation } \\
\text { in out-of-school activities, as did their healthy peers. Parents still afraid of } \\
\text { children engaged in PA }\end{array}$ & $\begin{array}{l}\text { Parents of children with controlled epilepsy should be } \\
\text { encouraged to take part in PA taking into account child's } \\
\text { preference }\end{array}$ \\
\hline $\begin{array}{l}\text { Italy } \\
2014^{37}\end{array}$ & $\begin{array}{l}\text { Consecutive patients at a tertiary care epilepsy } \\
\text { clinic, prospective, open personal interview } \\
\text { to identify seizure precipitants }\end{array}$ & $104 / 0$ & $\begin{array}{l}\text { Stress, sleep deprivation and fatigue were the most frequently reported } \\
\text { precipitants }\end{array}$ & $\begin{array}{l}\text { There was not an explicit remark on PA activity as a trigger } \\
\text { factor for seizures }\end{array}$ \\
\hline $\begin{array}{l}\text { South } \\
\text { Korea } \\
2014^{5}\end{array}$ & $\begin{array}{l}\text { Case series of children with BECTS assessing } \\
\text { PA program, EEG, seizure frequency, } \\
\text { psychological factors and quality of life } \\
\text { assessment }\end{array}$ & $10 / 10$ & $\begin{array}{l}\text { Neurocognitive domains such as visual, auditory sustained and divided attention, } \\
\text { psychomotor speed, as well as behavioral and social relations, mood-related } \\
\text { wellbeing and quality of life improved after exercise therapy }\end{array}$ & $\begin{array}{l}\text { PA may have a positive impact on neuropsychological factors. } \\
\text { Small sample size }\end{array}$ \\
\hline $\begin{array}{l}\text { Canada } \\
2015^{38}\end{array}$ & $\begin{array}{l}\text { Nova Scotia Childhood Epilepsy population- } \\
\text { based cohort. Injury inquiry }\end{array}$ & $472 / 0$ & $\begin{array}{l}81 \text { injuries. None of the accidents were the result of falls from bicycles and none } \\
\text { occurred during sporting activities }\end{array}$ & PA and sports seem to be safe for PWE \\
\hline $\begin{array}{l}\text { Thailand } \\
2015^{18}\end{array}$ & $\begin{array}{l}\text { Random, university epilepsy clinic, interview } \\
\text { and questionnaire }\end{array}$ & $203 / 0$ & $\begin{array}{l}\text { A total of } 47 \% \text { of the patients exercised at least three times per week, while 53\% } \\
\text { exercised two times or less a week }\end{array}$ & Epilepsy might be linked to sedentary lifestyle \\
\hline US $2015^{16}$ & $\begin{array}{l}\text { Data from the } 2010 \text { cross-sectional National } \\
\text { Health Interview Survey compared behavior }\end{array}$ & $480 / 26,659$ & $\begin{array}{l}\text { PWE were significantly less likely than adults without epilepsy to follow the } \\
\text { recommended PA guidelines for Americans ( } 35 \% \text { vs. } 46 \% \text { ) and to walk for at } \\
\text { least } 10 \text { minutes during the } 7 \text { days before being surveyed ( } 40 \% \text { vs. } 51 \% \text { ) }\end{array}$ & Epilepsy might be linked to sedentary lifestyle \\
\hline $\begin{array}{l}\text { UK } \\
2016^{39}\end{array}$ & Narrative analysis - qualitative research & $16 / 0$ & $\begin{array}{l}\text { PA creates a positive effect on psychological and physical wellbeing. Prevention } \\
\text { from PA per medical advice or recurrent seizures creates negative effects such } \\
\text { as social isolation, anxiety, lack of confidence, frustration and anger }\end{array}$ & $\begin{array}{l}\text { Treatment of anxiety, educational programs and being more } \\
\text { effective in the approach of drug-resistant epilepsy could } \\
\text { overcome barriers limiting participation in PA. Small sample } \\
\text { size }\end{array}$ \\
\hline $\begin{array}{l}\text { Canada } \\
2017^{40}\end{array}$ & $\begin{array}{l}\text { A self-administered questionnaire, parent-child } \\
\text { dyads. Validated HARCES parent scale and } \\
\text { modified-HARCES completed by the child }\end{array}$ & $21 / 0$ & $\begin{array}{l}\text { Total HARCES scores showed no agreement between parent and child pairs with } \\
\text { correlation of } 0.2798 \text { (95\% CI: } 0.173-0.635 \text { ) }\end{array}$ & $\begin{array}{l}\text { Youth with epilepsy face activity restrictions based on fear of } \\
\text { perceived risk of injury. Education strategies are needed to } \\
\text { overcome this barrier }\end{array}$ \\
\hline $\begin{array}{l}\text { Spain } \\
2017^{41}\end{array}$ & $\begin{array}{l}\text { Prospective controlled study with } \\
\text { questionnaires assessing quality of life and } \\
\text { daily habits }\end{array}$ & $85 / 193$ & $\begin{array}{l}\text { There was no difference in sports between the groups. PWE had a healthier } \\
\text { lifestyle (lower BMI, lower alcohol consumption and a tendency toward } \\
\text { smoking less) }\end{array}$ & $\begin{array}{l}\text { Spanish public policy and awareness favor participation of PWE } \\
\text { in PA }\end{array}$ \\
\hline $\begin{array}{l}\text { Brazil } \\
2017^{42}\end{array}$ & $\begin{array}{l}\text { Prospective study with questionnaires } \\
\text { assessing quality of life, PA and stigma }\end{array}$ & $67 / 0$ & $\begin{array}{l}\text { Most PWE are sedentary and do not practice PA for fear of seizures. Clinical } \\
\text { aspects of epilepsy negatively influence PA activity. Less PA is associated } \\
\text { with depressive disorder, worse quality of life and higher perception of stigma }\end{array}$ & $\begin{array}{l}\text { PA may have a positive impact on quality of life, emotional } \\
\text { status and cultural stigma }\end{array}$ \\
\hline $\begin{array}{l}\text { Brazil } \\
\quad 2017^{43}\end{array}$ & $\begin{array}{l}\text { Prospective study with questionnaires } \\
\text { assessing quality of life, emotional status, } \\
\text { side effects and PA }\end{array}$ & $101 / 0$ & $\begin{array}{l}\text { PA was positively associated with quality of life }(p<0.001) \text { and negatively } \\
\text { associated with depression }(p=0.046) \text {, state of anxiety }(p=0.014) \text {, trait of } \\
\text { anxiety }(p=0.015) \text { and side effects of medications }(p=0.01)\end{array}$ & $\begin{array}{l}\text { PA may have a positive impact on quality of life and emotional } \\
\text { status. Side effects may have a negative impact on exercise } \\
\text { engagement }\end{array}$ \\
\hline $\begin{array}{l}\text { UK } \\
2017^{44}\end{array}$ & $\begin{array}{l}\text { Semi-structured interviews - qualitative } \\
\text { research }\end{array}$ & $11 / 0$ & $\begin{array}{l}\text { PA motivators are: benefits on physical and mental health shown in an increase } \\
\text { in mood, higher social interaction and perceived improvement in overall } \\
\text { physical health. Barriers included a fear of injury, lack of social support and } \\
\text { exercise-induced seizures. Adaptation techniques used were self-monitoring } \\
\text { through the use of technology, reducing PA frequency and intensity level, and } \\
\text { exercising at certain times of the day. Medical professionals requesting } \\
\text { termination of some PA }\end{array}$ & $\begin{array}{l}\text { Remarkable effects of PA. Exercise engagement of PWE needs a } \\
\text { multifactorial and individual approach. Small sample size }\end{array}$ \\
\hline $\begin{array}{l}\text { Brazil } \\
\quad 2018^{45}\end{array}$ & Descriptive observational study & $101 / 0$ & $65 \%$ were physically inactive & Epilepsy might be linked to sedentary lifestyle \\
\hline
\end{tabular}

$\mathrm{AED}=$ antiepileptic drug; BECTS = benign epilepsy with centro-temporal spikes; BMI = body mass index; HARCES = the Hague Restrictions in Childhood Epilepsy Scale; JME = juvenile 
prejudice, stigmatization, fear, shame, lack of knowledge or medical advice.

\section{What are the Clinical Effects of PA in This Population?}

Animal models confirm a positive effect of PA on mood and seizure control. In a murine model of depression, PA was correlated with a decrease in negative mood symptoms as well as a delay in the development of epilepsy. ${ }^{23}$ This finding was associated with the production of galanin, a neuropeptide with antidepressant and anticonvulsive effects. ${ }^{24}$

PA and sports participation can have a positive impact on overall health status and quality of life of people living with chronic diseases such as depression, ${ }^{25}$ arthritis, ${ }^{26}$ asthma, ${ }^{27}$ hypertension and diabetes. ${ }^{28}$ People with epilepsy tend to be more sedentary than the general population, a finding associated with higher body mass index, minor physical resistance, low selfesteem, and increased likelihood of anxiety and depression. A Brazilian study documented that physical inactivity constitutes a risk factor for the development of depression and anxiety in PWE. ${ }^{29}$

In an Ohio-based study, a 12-week sports intervention program specifically designed for PWE generated enhanced quality of life scores in the PA group $(p<0.031)$ compared with controls $(p=0.943)$. Improvement was seen in variables such as selfimage, vitality and emotional state. ${ }^{30}$ Similarly, a study from the University of Alabama confirmed that adult PWE who practiced regular PA had lower levels of depression. ${ }^{31}$ In a Korean study, it was also observed that a program of regular PA in children with benign epilepsy with centrotemporal spikes (BECTS) generated improvements in attention, psychomotor speed, impulse control, inhibition/disinhibition and problem-solving skills. ${ }^{5}$ Overall, exercise seems to exert favorable effects on quality of life, neurocognitive domains and psychosocial function ${ }^{32,33}$ (Table 1).

The pleiotropic effects of antiepileptic drugs (AEDs) must also be considered. Some AEDs such as carbamazepine, lamotrigine, oxcarbazepine, valproate and clobazam can positively impact mood, while others such as levetiracetam, zonisamide, perampanel and phenobarbital can do the opposite. Moreover, some AEDs are known to promote weight gain (i.e., valproic acid, carbamazepine, vigabatrin, gabapentin and phenobarbital), whereas others may be associated with weight loss (i.e., topiramate, zonisamide and felbamate). ${ }^{46}$ Appropriate AED selection requires joint decision-making between patient and prescriber and a drug's side-effect profile should be discussed and fully considered before initiation.

\section{Does PA Reduce the Number of IED Seen on EEG and Impact Seizure Frequency?}

Electroencephalogram recordings in rats show IEDs decrease or disappearance during PA with returning of the interictal discharges at rest. One hypothesis for this finding is that increased vigilance and attention required in PA may reduce seizure frequency. ${ }^{47}$ Basic research has shown that short-duration swimming exercise $^{48}$ and short-, moderate- and long-duration treadmill exercises $^{49}$ consistently decreased the frequency of penicillininduced epileptiform activity in male Wistar rats. Likewise, a reduction in the number of clinical and electrographic seizures has been observed with both strengthening (i.e., weightlifting) and aerobic exercises. ${ }^{50,51}$
Findings in animal models may have direct observable clinical implications in humans. For instance, an analysis of video EEG recordings from 26 Norwegian children with epilepsy who attended an exercise program demonstrated a $25 \%$ decrease in IEDs in approximately $77 \%$ (20/26) of patients during exercise. IEDs increased in relation to baseline following cessation of exercise. ${ }^{4}$ High-intensity exercise has been shown to reduce seizure occurrence and paroxysmal EEG activity in people with temporal lobe and juvenile myoclonic epilepsy. ${ }^{34,35}$ Moreover, a population-based Swedish study demonstrated that low cardiovascular fitness status at 18 years of age correlated with an increased likelihood of developing epilepsy. The association remained even after controlling for several confounders such as family history, personal history of diabetes, stroke and traumatic head injury. The authors concluded that behaviors that increase cardiovascular fitness may act as positive disease-modifiers against the future development of epilepsy. ${ }^{52}$

\section{Which Mechanisms Related to PA Could Explain Improved Seizure Control?}

Data from animal studies would suggest that the putative neuroprotective effects of PA might be ascribed to various genetic, molecular, biochemical and structural changes. ${ }^{23,47,51,53,54}$ The proposed mechanisms include:

1. Release of $\beta$-endorphins from the opioid system ${ }^{55}$

2. Release of steroids secondary to stress ${ }^{56}$

3. Increase in melatonin concentrations ${ }^{57}$

4. Increase of parvo albumin in affected cells after seizures. This molecule has been linked to antiepileptogenic effects, cytoprotection and prevention of neuronal death in the affected cells. ${ }^{58}$

5. CA1 cells hyperreactivity reduction and generation of structural changes within the hippocampus, which may have an inhibitory effect on the occurrence of abnormal electrical discharges. $^{58,59}$

A study using a murine epileptogenic model by Arida et $\mathrm{al}^{60}$ suggested that greater effort was needed to induce epileptogenesis in physical trained animals. The delay in seizure occurrence was attributed to the inhibitory effect of noradrenaline and GABA released during exercise. ${ }^{27,61}$ Additionally, exercise resulted in decreased production of oxidants and free radicals. ${ }^{50}$

In a pentylenetetrazol murine model used to assess the effect of swimming on epileptogenesis after 6 weeks of practice, the exercise group had a greater latency to first seizure, shorter seizure duration, lower amplitude and frequency of IEDs, increased superoxide dismutase activity and non-protein sulfhydryl levels, and greater attenuation of oxidant production. ${ }^{62}$

Similarly, a Polish study that used a pilocarpine murine model of focal epilepsy determined that animals undergoing a PA program had a longer latency in the appearance of status epilepticus and demonstrated lower intensity and shorter seizure duration. ${ }^{53}$ Possible hypotheses for these observations include increased angiogenesis resulting in decreased excitotoxicity, ${ }^{63,64}$ release of neuroprotective trophic factors and expression of neuronal growth factors ${ }^{65,66}$

\section{Can PA Adversely Affect Seizure Control?}

Sporadic case reports of PA-induced seizures should be weighed against the relatively numerous and well-established 
Table 2: Seizure induction by exercise

\begin{tabular}{|c|c|c|c|c|c|}
\hline $\begin{array}{l}\text { Author/ } \\
\text { year }\end{array}$ & Country & Population $(N)$ & $\begin{array}{l}\text { Exercise-induced seizures/ } \\
\text { EEG epileptiform discharge } \\
\text { increasing definition }\end{array}$ & Patients with seizure induction & Clinical relevance \\
\hline $\begin{array}{c}\text { Ogunyemi } \\
1988^{67}\end{array}$ & Canada & Three adults & $\begin{array}{l}\text { Seizures triggered by exercise } \\
\text { in patients with epilepsy } \\
\text { diagnosis }\end{array}$ & $\begin{array}{l}\text { Three patients with generalized epileptic seizures and epileptic discharges in } \\
\text { the EEG during exercise (running) and normal EEG during resting } \\
\text { wakefulness and sleep }\end{array}$ & $\begin{array}{l}\text { In three PWE, there was seizure occurrence in the post } \\
\text { exercise period }\end{array}$ \\
\hline $\begin{array}{r}\text { Simpson } \\
1989^{68}\end{array}$ & United States & Three adults & $\begin{array}{l}\text { Seizures exclusively triggered } \\
\text { by exercise in patients } \\
\text { without diagnosis of } \\
\text { epilepsy }\end{array}$ & $\begin{array}{l}\text { Three patients had convulsions while running. All of them debuted with } \\
\text { seizures and were diagnosed with frontal cortex lesions }\end{array}$ & $\begin{array}{l}\text { A seizure after high-intensity exercise might provide and } \\
\text { early warning of the presence of an intracranial mass } \\
\text { lesion }\end{array}$ \\
\hline $\begin{array}{r}\text { Bjørholt } \\
1990^{69}\end{array}$ & Norway & $\begin{array}{l}44 \text { adult } \\
\text { inpatients with } \\
\text { active epilepsy }\end{array}$ & $\begin{array}{l}\text { Presence of a clinical seizure } \\
\text { during or after the bicycle } \\
\text { ergometer test }\end{array}$ & One patient ( $2 \%)$ had a single seizure immediately after the physical test & $\begin{array}{l}\text { In } 2 \% \text { of PWE there was seizure occurrence in the post } \\
\text { exercise period }\end{array}$ \\
\hline $\begin{array}{l}\text { Schmitt } \\
1994^{70}\end{array}$ & Switzerland & Two children & $\begin{array}{l}\text { Seizures triggered by exercise } \\
\text { in patients with epilepsy } \\
\text { diagnosis }\end{array}$ & $\begin{array}{l}\text { Two patients with ataxia, developmental delay and epilepsy presented } \\
\text { seizures and epileptic discharges in the EEG clearly induced by physical } \\
\text { exercise }\end{array}$ & $\begin{array}{l}\text { In two children with epilepsy appeared drug-resistant } \\
\text { seizures associated to PA. Only the strict avoidance of } \\
\text { physical exercise reduced seizure frequency }\end{array}$ \\
\hline $\begin{array}{c}\text { Eriksen } \\
1994^{71}\end{array}$ & Norway & $\begin{array}{l}14 \text { outpatient } \\
\text { women with } \\
\text { drug-resistant } \\
\text { epilepsy }\end{array}$ & $\begin{array}{l}\text { Presence of a clinical seizure } \\
\text { during or after the aerobic } \\
\text { dancing test }\end{array}$ & $\begin{array}{l}\text { 28\% showed increase in the weekly seizure frequency and } 72 \% \text { showed } \\
\text { decreased in the weekly seizure frequency } \\
\text { During aerobic exercise, 50\% subjects had seizures; the remaining 50\% } \\
\text { subjects had none. Most seizures occurred during aerobic dancing or } \\
\text { during the cooling down period }\end{array}$ & $\begin{array}{l}\text { In } 28 \% \text { of the women with drug-resistant epilepsy, exercise } \\
\text { appeared to be a seizure precipitant }\end{array}$ \\
\hline $\begin{array}{c}\text { Nakken } \\
1997^{4}\end{array}$ & Norway & $\begin{array}{l}26 \text { inpatient } \\
\text { children with } \\
\text { difficult to } \\
\text { treat epilepsy }\end{array}$ & $\begin{array}{l}>30 \% \text { increase in the EEG } \\
\text { discharges during exercise } \\
\text { or in the post exercise period }\end{array}$ & $\begin{array}{l}15 \% \text { showed increase in the EEG discharges during exercise } \\
\text { Two of the four had a further increase in the EEG discharges in the post } \\
\text { exercise period. These four patients }(15 \%) \text { informed the authors in } \\
\text { advance that they previously had experienced seizures during and/or } \\
\text { immediately after exercise }\end{array}$ & $\begin{array}{l}\text { In } 15 \% \text { of children with epilepsy there was an increase in the } \\
\text { EEG discharges during or in the post exercise period. } \\
\text { None of the patients suffered a seizure during or after the } \\
\text { test }\end{array}$ \\
\hline $\begin{array}{l}\text { Nakken } \\
1999^{10}\end{array}$ & Norway & $\begin{array}{l}204 \text { adult } \\
\text { outpatients } \\
\text { with active } \\
\text { epilepsy }\end{array}$ & $\begin{array}{l}\text { Having seizures in }>50 \% \text { of } \\
\text { the training sessions }\end{array}$ & $\begin{array}{l}2 \% \text { had genuine exercise-induced seizures } \\
10 \% \text { of the patients were prone to have seizures while exercising } \\
8 \% \text { of patients frequently experienced seizures in the immediate post } \\
\text { exercise period } \\
10 \% \text { experienced injuries in connection with physical exercise and } \\
\text { seizures }\end{array}$ & $\begin{array}{l}\text { In } 10 \% \text { of the PWE, exercise appeared to be a seizure } \\
\text { precipitant, and this applied particularly to those with focal } \\
\text { lesional epilepsy }\end{array}$ \\
\hline $\begin{array}{l}\text { Sturm } \\
2002^{72}\end{array}$ & Australia & $\begin{array}{l}\text { A } 16 \text { and a } 28- \\
\text { year-old male } \\
\text { patients }\end{array}$ & $\begin{array}{l}\text { Having seizures in }>80 \% \text { of } \\
\text { the training sessions }\end{array}$ & $\begin{array}{l}\text { Two patients with TLE presented seizures and epileptic discharges in the } \\
\text { EEG clearly induced by physical exercise } \\
\text { Seizures occurred within 5-20 minutes of commencing activities such as } \\
\text { running and playing soccer or tennis and were more likely if the exercise } \\
\text { was strenuous }\end{array}$ & $\begin{array}{l}\text { Almost all of the patients' seizures were triggered by PA, } \\
\text { suggesting that this is a form of temporal lobe reflex } \\
\text { epilepsy }\end{array}$ \\
\hline $\begin{array}{l}\text { Werz } \\
2005^{73}\end{array}$ & United States & 1 adult patient & $\begin{array}{l}\text { Seizures exclusively triggered } \\
\text { by exercise }\end{array}$ & $\begin{array}{l}\text { This is a case of a young woman who had three episodes of generalized } \\
\text { tonic-clonic seizures always associated with exercise. This case is } \\
\text { unusual as no seizures were identified independent of exercise }\end{array}$ & $\begin{array}{l}\text { Rarely, seizures may be limited exclusively to exercise and } \\
\text { this may be documented by EEG recording during } \\
\text { simultaneous cardiac exercise testing }\end{array}$ \\
\hline $\begin{array}{l}\text { Kamel } \\
2014^{74}\end{array}$ & Australia & $\begin{array}{l}10 \text { adult patients } \\
\text { from a tertiary } \\
\text { epilepsy care } \\
\text { center }\end{array}$ & $\begin{array}{l}\text { Seizures triggered by different } \\
\text { types of exercise }\end{array}$ & $\begin{array}{l}\text { This is a case series of } 10 \text { patients with TLE. Various forms of exercise were } \\
\text { described among the patients including running, swimming, playing } \\
\text { netball, dancing, cycling, weight lifting, and martial arts } \\
90 \% \text { of cases suffered left TLE }\end{array}$ & $\begin{array}{l}\text { Although regular exercise should generally be encouraged in } \\
\text { PWE, this is not the case once a clear exercise-related } \\
\text { trigger has been identified }\end{array}$ \\
\hline $\begin{array}{l}\text { Collard } \\
2017^{44}\end{array}$ & $\begin{array}{l}\text { United } \\
\text { Kingdom }\end{array}$ & 11 adult patients & $\begin{array}{l}\text { Qualitative study } \\
\text { No quantitative data }\end{array}$ & $\begin{array}{l}\text { Some of the participants reported exercise to be a trigger for their epilepsy. } \\
\text { This was in connection with high-intensity exercise and overheating }\end{array}$ & $\begin{array}{l}\text { The adaptations used and developed by the participants } \\
\text { revealed that although certain aspects of exercise may } \\
\text { trigger seizures for some, they felt continuing to exercise } \\
\text { with adaptations was more beneficial to their overall } \\
\text { mental health }\end{array}$ \\
\hline
\end{tabular}


benefits of PA (Table 2). Based on scant data, up to 2-10\% of PWE may have exercise-induced seizures (defined as seizures occurring in $>50 \%$ of training sessions). ${ }^{10,69}$ These case reports describe patients with both genetic generalized epilepsies ${ }^{67,73}$ as well as symptomatic focal epilepsies ${ }^{71}$ of frontal ${ }^{68}$ and temporal lobe origin. $^{72,74}$

A review of the limited literature on this subject would indicate that the occurrence of exercise-induced seizures is overall quite rare. $^{4,10}$ Of interest, PA-induced seizures have been mainly attributed to high-intensity exercise such as ball games, jogging, running and hiking. In addition, high altitude may also provoke seizures, due in part to hypoxia and hypocapnic hyperventilation.

Some patients are reported to present with a high frequency of seizures happening either often ( $>80 \%$ of the time) or exclusively occurring during PA. The authors surmise that these patients may have a form of temporal lobe reflex epilepsy ${ }^{70,72,74}$ and that the temporal lobe might be uniquely more sensitive to the generation of exercise-induced IEDs compared with other cortical areas. In these cases, complex partial seizures might be most susceptible to activation during exercise. $^{75}$

Arida et $\mathrm{al}^{76}$ correlated the occurrence of PA-induced seizures with homeostatic alterations linked to general fatigue, psychic stress of competition, hypoxia, hypoglycemia, hyperhydration, hyponatremia and hyperthermia. It is known, for instance, that hyperventilation may frequently induce absence seizures and some focal seizures in patients at rest. It has been theorized that resting hyperventilation might trigger seizures due to respiratory alkalosis. However, this explanation is unlikely to be compelling in the case of exercise, which tends to result in metabolic acidosis.

\section{Discussion}

Epilepsy is associated with reduced sports participation and PA in PWE. Family, peers and educators may discourage PA due to the mistaken belief that epileptic seizures during exercise could lead to psychological and social stigma and adversely impact quality of life. ${ }^{77,78}$ As PWE replace "outdoor" activities with "indoor" sedentary programs, physical exercise levels may further decline. ${ }^{79}$

Healthcare teams should extol the virtues of PA, which include: (1) better social integration, (2) improvement of depression and anxiety, (3) protection against osteopenia/osteoporosis, (4) enhanced sleep, (5) positive effects on quality of life and (6) possible reduction in seizure frequency. ${ }^{76}$

Education on the topic is essential and should extend to community, educators, patients and families. To achieve greater participation of PWE in sports, necessary infrastructure must be developed addressing issues such as accessibility, transportation and safety. ${ }^{8}$

The International League Against Epilepsy (ILAE) has proposed some recommendations concerning PA in children: in aquatic sports, one should weigh risks and benefits; in highaltitude sports such as rock climbing or tree climbing, it is noted that "regardless of whether the child has epilepsy, common sense prevails"; cycling, skating or skateboarding should be limited if there is inadequate seizure control or if epilepsy was recently diagnosed; on contact sports the ILAE states that mild traumatic head injury is unlikely to precipitate an epileptic seizure; finally, diving, parachuting and similar sports should be avoided. ${ }^{80}$
In 2016, the ILAE published a report that divided sports into low, moderate and high-risk categories. The level of risk should be considered along with variables such as type of sport, probability of seizures, type and severity of seizures, precipitating factors, diurnal variation, protective measures and patient risk tolerance. Ultimately, the report eschews blanket recommendations in favor of a patient-specific approach. ${ }^{8}$ It is advised that high-performance athletes with epilepsy should inform coaches, training staff and sport committees about their pharmacotherapy to protect themselves from charges of doping. ${ }^{81}$

Rarely, exercise can have an activity on seizure occurrence, ${ }^{67-74}$ and clinicians must be attuned to this possibility. In some cases, the possibility of a temporal reflex epilepsy must be considered, and clinicians should ask their patients whether specific activities lead to seizures. If a specific PA is identified as a trigger, it is advisable to record an EEG during this activity. Should such an activity be associated with the occurrence or increase in IEDs or result in seizure, avoidance may be prudent. Alternatively, the patient and clinician may also consider reducing frequency and intensity of the specific exercise, greater supervision during the activity and initiation of preventive antiepileptic therapy.

\section{Conclusions}

People with epilepsy are less physically active and less likely to be involved in sports than their peers. Data supporting the beneficial effects of PA on seizure control are insufficient. However, various positive effects on neuropsychological, emotional and quality of life measures have been documented. There is intriguing data to suggest that PA may reduce IED frequency and seizure occurrence, and thereby serve as a useful adjunctive therapy for the treatment of epilepsy. Stakeholders must be aware of various clinical, psychological and socio-economic barriers that limit PA in PWE. The benefits of PA should be analyzed as part of a holistic approach to patient health.

\section{Statement of Authorship}

Study concept and design: JCM, LDL. Literature review: DMCV, JPOH, VBC, LDL. Interpretation of data: JFTZ, JCM, LDL, SR. Drafting of manuscript and revisions: JFTZ, JCM, LDL, SR, VBC.

\section{Disclosures}

JFTZ receives grants from the University of Saskatchewan, the Royal University Hospital Foundation in Saskatoon, Saskatchewan, and the Saskatchewan Health Research Foundation. JCM, LDL, SR, VBC, DMCV and JPOH have nothing to disclose. None of the authors have any conflict of interest to declare.

\section{REFERENCES}

1. World Health Organization. Epilepsy Fact sheet: Bulletin 999 2017 [cited 2017 December 5]. Available at: http://www.who.int/ mediacentre/factsheets/fs999/en/.

2. Rai D, Kerr MP, McManus S, Jordanova V, Lewis G, Brugha TS. Epilepsy and psychiatric comorbidity-a nationally representative population-based study: epilepsy and psychiatric morbidity. Epilepsia. 2012;53(6):1095-3.

3. Arida RM, Scorza FA, Cavalheiro EA, Perucca E, Moshé SL. Can people with epilepsy enjoy sports? Epilepsy Res. 2012;98 (1):94-5.

4. Nakken KO, Løyning A, Løyning T, Gløersen G, Larsson PG. Does physical exercise influence the occurrence of epileptiform EEG discharges in children? Epilepsia. 1997;38(3):279-84. 
5. Eom S, Lee MK, Park J-H, et al. The impact of an exercise therapy on psychosocial health of children with benign epilepsy: a pilot study. Epilepsy Behav. 2014;37:151-6.

6. Arida RM. Impact of physical exercise therapy on behavioral and psychosocial aspects of epilepsy. Epilepsy Behav. 2014;40:90-1.

7. Arida RM, Scorza FA, da Silva SG, Schachter SC, Cavalheiro EA. The potential role of physical exercise in the treatment of epilepsy. Epilepsy Behav. 2010;17(4):432-5.

8. Capovilla G, Kaufman KR, Perucca E, Moshé SL, Arida RM. Epilepsy, seizures, physical exercise, and sports: a report from the ILAE Task Force on sports and epilepsy. Epilepsia. 2016;57 (1):6-12.

9. Elliott JO, Moore JL, Lu B. Health status and behavioral risk factors among persons with epilepsy in Ohio based on the 2006 Behavioral Risk Factor Surveillance System. Epilepsy Behav. 2008;12 (3):434-4.

10. Nakken KO. Physical exercise in outpatients with epilepsy. Epilepsia. 1999;40(5):643-51.

11. Ablah E, Haug A, Konda K, et al. Exercise and epilepsy: a survey of Midwest epilepsy patients. Epilepsy Behav. 2009;14 (1):162-6.

12. Steinhoff BJ, Neusüss K, Thegeder H, Reimers CD. Leisure time activity and physical fitness in patients with epilepsy. Epilepsia. 1996;37(12):1221-7.

13. Arida RM, Scorza FA, de Albuquerque M, Cysneiros RM, de Oliveira RJ, Cavalheiro EA. Evaluation of physical exercise habits in Brazilian patients with epilepsy. Epilepsy Behav. 2003;4 (5):507-10.

14. Han K, Choi-Kwon S, Lee S-K. Leisure time physical activity in patients with epilepsy in Seoul, South Korea. Epilepsy Behav. 2011;20(2):321-5.

15. Hinnell C, Williams J, Metcalfe A, et al. Health status and healthrelated behaviors in epilepsy compared to other chronic conditions-a national population-based study: health status and behaviors in epilepsy. Epilepsia. 2010;51(5):853-61.

16. Cui W, Zack MM, Kobau R, Helmers SL. Health behaviors among people with epilepsy-results from the 2010 National Health Interview Survey. Epilepsy Behav. 2015;44:121-6.

17. Wong J, Wirrell E. Physical activity in children/teens with epilepsy compared with that in their siblings without epilepsy. Epilepsia. 2006;47(3):631-9.

18. Saengsuwan J, Boonyaleepan S, Tiamkao S. Diet, exercise, sleep, sexual activity, and perceived stress in people with epilepsy in NE Thailand. Epilepsy Behav. 2015;45:39-43.

19. Chong J, Kudrimoti HS, Lopez DC, Labiner DM. Behavioral risk factors among Arizonans with epilepsy: Behavioral Risk Factor Surveillance System 2005/2006. Epilepsy Behav. 2010;17 (4):511-9.

20. Jalava M, Sillanpää M. Physical activity, health-related fitness, and health experience in adults with childhood-onset epilepsy: a controlled study. Epilepsia. 1997;38(4):424-9.

21. Elliott JO, Lu B, Moore JL, McAuley JW, Long L. Exercise, diet, health behaviors, and risk factors among persons with epilepsy based on the California Health Interview Survey, 2005. Epilepsy Behav. 2008;13(2):307-15.

22. Gordon KE, Dooley JM, Brna PM. Epilepsy and activity-a population-based study: epilepsy and activity. Epilepsia. 2010;51 (11):2254-9.

23. Epps SA, Kahn AB, Holmes PV, Boss-Williams KA, Weiss JM, Weinshenker D. Antidepressant and anticonvulsant effects of exercise in a rat model of epilepsy and depression comorbidity. Epilepsy Behav. 2013;29(1):47-52.

24. Lerner JT, Sankar R, Mazarati AM. Galanin and epilepsy. EXS. 2010;102:183-94.

25. Babyak M, Blumenthal JA, Herman S, et al. Exercise treatment for major depression: maintenance of therapeutic benefit at 10 months. Psychosom Med. 2000;62(5):633-8.

26. Gupta R, Aggarwal A. Exercise and rheumatoid arthritis: a low-cost intervention with major benefits. Natl Med J India. 2015;28 (3):132-3

27. Westergren T, Fegran L, Nilsen T, Haraldstad K, Kittang OB, Berntsen S. Active play exercise intervention in children with asthma: a pilot study. BMJ Open. 2016;6(1):e009721.
28. Haxhi J, Leto G, di Palumbo AS, et al. Exercise at lunchtime: effect on glycemic control and oxidative stress in middle-aged men with type 2 diabetes. Eur J Appl Physiol. 2016;116(3):573-82.

29. de Lima C, de Lira CAB, Arida RM, et al. Association between leisure time, physical activity, and mood disorder levels in individuals with epilepsy. Epilepsy Behav. 2013;28(1):47-51.

30. McAuley JW, Long L, Heise J, et al. A prospective evaluation of the effects of a 12-week outpatient exercise program on clinical and behavioral outcomes in patients with epilepsy. Epilepsy Behav. 2001;2(6):592-600.

31. Roth DL, Goode KT, Williams VL, Faught E. Physical exercise, stressful life experience, and depression in adults with epilepsy. Epilepsia. 1994;35(6):1248-55.

32. Götze W, Kubicki S, Munter M, Teichmann J. Effect of physical exercise on seizure threshold (investigated by electroencephalographic telemetry). Dis Nerv Syst. 1967;28(10):664-7.

33. Horyd W, Gryziak J, Niedzielska K, Zieliński JJ. Effect of physical exertion on seizure discharges in the EEG of epilepsy patients. Neurol Neurochir Pol. 1981;15(5-6):545-2.

34. Vancini RL, de Lira CAB, Scorza FA, et al. Cardiorespiratory and electroencephalographic responses to exhaustive acute physical exercise in people with temporal lobe epilepsy. Epilepsy Behav. 2010;19(3):504-8.

35. De Lima C, Vancini RL, Arida RM, et al. Physiological and electroencephalographic responses to acute exhaustive physical exercise in people with juvenile myoclonic epilepsy. Epilepsy Behav. 2011;22:718-22.

36. Engel - Yeger B, Zlotnik S, Shahar E. Childhood-onset primary generalized epilepsy-impacts on children's preferences for participation in out-of-school activities. Epilepsy Behav. 2014;34 (1): $1-5$.

37. Ferlisi M, Shorvon S. Seizure precipitants (triggering factors) in patients with epilepsy. Epilepsy Behav. 2014;33:101-5.

38. Camfield C, Camfield P. Injuries from seizures are a serious, persistent problem in childhood onset epilepsy: a populationbased study. Seizure. 2015;27:80-3.

39. Collard SS, Marlow C. The psychosocial impact of exercising with epilepsy: a narrative analysis. Epilepsy Behav. 2016;61:199-205.

40. Brna PM, Gordon KE, Woolridge E, Dooley JM, Wood E. Perceived need for restrictions on activity for children with epilepsy. Epilepsy Behav. 2017;73:236-9.

41. Aguirre C, Quintas S, Ruiz-Tornero AM, et al. Do people with epilepsy have a different lifestyle? Epilepsy Behav. 2017;74:27-32.

42. Almeida-Souza-Tedrus GM, Sterca GS, Buarque PR. Physical activity, stigma, and quality of life in patients with epilepsy. Epilepsy Behav. 2017;77:96-8.

43. Häfele CA, Freitas MP, da Silva MC, Rombaldi AJ. Are physical activity levels associated with better health outcomes in people with epilepsy? Epilepsy Behav. 2017;72:28-34.

44. Collard SS, Ellis- Hill C. How do you exercise with epilepsy? Insights into the barriers and adaptations to successfully exercise with epilepsy. Epilepsy Behav. 2017;70:66-71.

45. Häfele CA, Freitas MP, Gervini BL, de Carvalho RM, Rombaldi AJ. Who are the individuals diagnosed with epilepsy using the Public Health System in the city of Pelotas, southern Brazil? Epilepsy Behav. 2018;78:84-90.

46. Ben-Menachem E. Weight issues for people with epilepsya review. Epilepsia. 2007;48:42-5.

47. Hellier JL, Dudek FE. Spontaneous motor seizures of rats with kainate-induced epilepsy: effect of time of day and activity state. Epilepsy Res. 1999;35(1):47-57.

48. Tutkun E, Ayyildiz M, Agar E. Short-duration swimming exercise decreases penicillin-induced epileptiform EcoG activity in rats. Acta Neurobiol Exp (Wars). 2010;70(4):382-9.

49. Kayacan Y, Tutkun E, Arslan G, Ayyildiz M, Agar E. The effects of treadmill exercise on penicillin-induced epileptiform activity. Arch Med Sci. 2016;12(5):935-40.

50. Radak Z, Chung HY, Goto S. Systemic adaptation to oxidative challenge induced by regular exercise. Free Radic Biol Med. 2008;44(2):153-9.

51. Peixinho-Pena LF, Fernandes J, de Almeida AA, et al. A strength exercise program in rats with epilepsy is protective against seizures. Epilepsy Behav. 2012;25(3):323-8. 
52. Nyberg J, Aberg MAI, Toren K, Nilsson M, Ben-Menachem E, Kuhn HG. Cardiovascular fitness and later risk of epilepsy: a Swedish population-based cohort study. Neurology. 2013;81(12):1051-7.

53. Setkowicz Z, Mazur A. Physical training decreases susceptibility to subsequent pilocarpine-induced seizures in the rat. Epilepsy Res. 2006;71(2-3):142-8.

54. Arida RM, Scorza FA, dos Santos NF, Peres CA, Cavalheiro EA. Effect of physical exercise on seizure occurrence in a model of temporal lobe epilepsy in rats. Epilepsy Res. 1999;37(1):45-52.

55. Contet C, Gavériaux-Ruff C, Matifas A, Caradec C, Champy M-F, Kieffer BL. Dissociation of analgesic and hormonal responses to forced swim stress using opioid receptor knockout mice. Neuropsychopharmacology. 2006;31(8):1733-44.

56. Arida RM, Scorza FA, Toscano-Silva M, Cavalheiro EA. Does exercise correct dysregulation of neurosteroid levels induced by epilepsy? Ann Neurol. 2010;68(6):971-2.

57. Mevissen M, Ebert U. Anticonvulsant effects of melatonin in amygdala-kindled rats. Neurosci Lett. 1998;257(1):13-6.

58. Arida RM, Scorza CA, Scorza FA, Gomes da Silva S, da Graça Naffah-Mazzacoratti M, Cavalheiro EA. Effects of different types of physical exercise on the staining of parvalbuminpositive neurons in the hippocampal formation of rats with epilepsy. Prog Neuropsychopharmacol Biol Psychiatry. 2007;31 (4):814-22.

59. Arida RM, Sanabria ERG, da Silva AC, Faria LC, Scorza FA, Cavalheiro EA. Physical training reverts hippocampal electrophysiological changes in rats submitted to the pilocarpine model of epilepsy. Physiol Behav. 2004;83(1):165-71.

60. Arida RM, de Jesus Vieira A, Cavalheiro EA. Effect of physical exercise on kindling development. Epilepsy Res. 1998;30 (2): 127-32.

61. Yoneda Y, Kanmori K, Ida S, Kuriyama K. Stress-induced alterations in metabolism of gamma-aminobutyric acid in rat brain. J Neurochem. 1983;40(2):350-6.

62. Souza MA, Oliveira MS, Furian AF, et al. Swimming training prevents pentylenetetrazol-induced inhibition of $\mathrm{Na}+, \mathrm{K}+$-ATPase activity, seizures, and oxidative stress. Epilepsia. 2009;50 (4):811-23.

63. Black JE, Isaacs KR, Anderson BJ, Alcantara AA, Greenough WT. Learning causes synaptogenesis, whereas motor activity causes angiogenesis, in cerebellar cortex of adult rats. Proc Natl Acad Sci USA. 1990;87(14):5568-72.

64. Kleim JA, Cooper NR, VandenBerg PM. Exercise induces angiogenesis but does not alter movement representations within rat motor cortex. Brain Res. 2002;934(1):1-6.

65. Nisticò G, Ciriolo MR, Fiskin K, Iannone M, de Martino A, Rotilio G. NGF restores decrease in catalase activity and increases superoxide dismutase and glutathione peroxidase activity in the brain of aged rats. Free Radic Biol Med. 1992;12 (3): $177-81$

66. Carro E, Trejo JL, Busiguina S, Torres-Aleman I. Circulating insulinlike growth factor I mediates the protective effects of physical exercise against brain insults of different etiology and anatomy. J Neurosci Off J Soc Neurosci. 2001;21(15):5678-84.

67. Ogunyemi AO, Gomez MR, Klass DW. Seizures induced by exercise. Neurology. 1988;38(4):633-4.

68. Simpson RK Jr, Grossman RG. Seizures after jogging. N Engl J Med. 1989;321(12):835.

69. Bjørholt PG, Nakken KO, Røhme K, Hansen H. Leisure time habits and physical fitness in adults with epilepsy. Epilepsia. 1990;31 (1):83-7.

70. Schmitt B, Thun-Hohenstein L, Vontobel H, Boltshauser E. Seizures induced by physical exercise: report of two cases. Neuropediatrics. 1994;25(01):51-3.

71. Eriksen HR, Ellertsen B, Grønningsaeter H, Nakken KO, Løyning Y, Ursin H. Physical exercise in women with intractable epilepsy. Epilepsia. 1994;35(6):1256-64.

72. Sturm JW, Fedi M, Berkovic SF, Reutens DC. Exercise-induced temporal lobe epilepsy. Neurology. 2002;59(8):1246-8.

73. Werz MA. Idiopathic generalized tonic-clonic seizures limited to exercise in a young adult. Epilepsy Behav. 2005;6(1): 98-101.

74. Kamel JT, Badawy RA, Cook MJ. Exercise-induced seizures and lateral asymmetry in patients with temporal lobe epilepsy. Epilepsy Behav Case Rep. 2014;2:26-30.

75. Bennett DR. Sports and epilepsy: to play or not to play. Semin Neurol. 1981;1:345-57.

76. Arida RM, Cavalheiro EA, da Silva AC, Scorza FA. Physical activity and epilepsy: proven and predicted benefits. Sports Med Auckl NZ. 2008;38(7):607-15.

77. Rodenburg R, Meijer AM, Scherphof C, et al. Parenting and restrictions in childhood epilepsy. Epilepsy Behav. 2013;27 (3):497-503.

78. Mecarelli O, Messina P, Capovilla G, et al. An educational campaign toward epilepsy among Italian primary school teachers. Epilepsy Behav. 2014;32:84-91.

79. Painter E, Rausch JR, Modi AC. Changes in daily activity patterns of caregivers of children with newly diagnosed epilepsy: a casecontrolled design. Epilepsy Behav. 2014;31:1-6.

80. ILAE Commission Report. Restrictions for children with epilepsy. Commission of Pediatrics of the ILAE. International League Against Epilepsy. Epilepsia. 1997;38(9):1054-6.

81. Kaufman KR. Anticonvulsants in sports: ethical considerations. Epilepsy Behav. 2007;10(2):268-71. 